\title{
NILAI FAEDAGOGI PERKAWINAN ETNIS MELAYU DI DESA SAKO KECAMATAN RAMBUTAN KABUPATEN BANYUASIN
}

\author{
Oleh: Jeki Sepriady* \\ *Program Studi Pendidikan Sejarah, FKIP Universitas PGRI Palembang
}

\begin{abstract}
ABSTRAK
Perkawinan dalam adat Melayu merupakan fase life cycle yang memiliki nilai moral (sakral) dan amat penting. Oleh sebab itu, keterlibatan dalam upacara perkawinan tersebut tidak hanya pasangan pengantin saja, tetapi juga keluarga, kerabat dekat kedua belah pihak. Penelitian ini berjudul "Adat Perkawinan Etnis Melayu di Desa Sako Kecamatan Rambutan Kabupaten Banyuasin". Adapun rumusan masalah penelitian ini: Nilai faedagogik apasajakah dalam Adat Perkawinan Etnis Melayu di Desa Sako Kecamatan Rambutan Kabupaten Banyuasin. Tujuan penelitian adalah 1. Untuk mengungkapkan nilai fedagogik Adat Perkawinan Etnis Melayu di Desa Sako Kecamatan Rambutan Kabupaten Banyuasin.. Metode yang digunakan dalam penelitian ini adalah metode deskriptif kualitatif adalah metode yang membicarakan berupa pengamatan wawancara atau penelaahan dokumen, penelitian ini secara sistematis ada kegiatan pokok yang dilakukan yaitu: Teknik pengumpulan data melalui studi kepustakaan, wawancara, observasi (pengamatan). Dokumentasi, berbentuk gambar. Teknik analisis data yang digunakan adalah analisis kualitatif suatu analisis yang tidak menggunakan angka-angka tetapi berupa penjelasan-penjelasan. Dari hasil penelitian dapat disimpulkan bahwa Adat Perkawinan Etnis Melayu di Desa Sako Kecamatan Rambutan Kabupaten Banyuasin memiliki beberapa tahapan dari sebelum perkawinan, proses perkawinan sampai sesudah perkawinan.
\end{abstract}

Kata Kunci: Nilai Faedagogi, Etnis Melayu, Desa Sako

\section{A. PENDAHULUAN}

Indonesia adalah negara kepulauan yang dilalui oleh garis khatulistiwa dan terletak antara lautan Teduh dan samudera Indonesia. Penduduknya berasal dan berdiam di pulau-pulau yang beraneka ragam adat budaya dan aturan. Perbedaan tersebut karena sejarah perkembangan budayanya dari zaman Melayu Polinesia, pergaulan hidup, tempat kediaman dan lingkungan alamnya berbeda. Selanjutnya perkembangan masyarakat Negara Kesatuan Republik Indonesia lebih banyak di pengaruhi agama Hindu, Islam dan Kristen. Lahirnya Republik Indonesia dapat menciptakan satu kesatuan dan cita-cita dari berbagai masyarakat adat yang berbedabeda, yang dikenal dengan semboyan "Bhineka Tunggal Ika" walaupun berbedabeda menjadi satu kesatuan dalam wadah Negara Pancasila (Hadikusuma, 1997:11) Sistem nilai budaya, pandangan hidup, dan ideologi merupakan sistem nilai budaya yang paling tinggi dan paling abstrak dari adat istiadat. Hal ini disebabkan karena nilai-nilai budaya merupakan konsep-konsep mengenai apa yang hidup dalam alam pikiran mengenai apa yang mereka angg ap bernilai, berharga (Koenjaraningrat, 2009:190).

Adanya tata-tertib adat perkawinan antara masyarakat adat yan.g satu dengan masyarakat adat yang lain, antara suku yang satu dengan suku yang lain, antara umat beragama dengan umat beragama yang lainnya, begitu pula antara masyarakat desa dan masyarakat kota. Dengan adanya perbedaan tata-tertib adat tersebut, maka seringkali dalam menyelesaikan perkawinan antar adat menjadi permasalahan yang berlarut-larut, bahkan kadang-kadang tidak tercapai kesepakatan antara kedua belah pihak dan 
menimbulkan ketegangan (Hadikusuma, 1997:12).

Perkawinan ialah ikatan lahir bathin antara seorang pria dengan seorang wanita sebagai suami istri dengan tujuan membentuk keluarga (rumah tangga) yang bahagia dan kekal berdasarkan Ketuhanan Yang Maha Esa. Didalam Pancasila bahwa perkawinan ditegaskan lebih rinci sebagai negara yang berdasarkan Pancasila, dimana sila pertama adalah Ketuhanan Yang Maha Esa, maka perkawinan mempunyai hubungan yang erat dengan agama atau kerohanian, sehingga perkawinan bukan saja mempunyai unsur lahir jasmani, tetapi unsur bathin atau rohani yang mempunyai peranan penting (Sudarsono, 2010:9).

Dalam adat Melayu perkawinan merupakan fase yang memiliki nilai moral (sakral) dan amat penting. Oleh sebab itu, keterlibatan dalam upacara perkawinan tersebut tidak hanya pasangan pengantin saja, tetapi juga keluarga, kerabat dekat kedua belah pihak. Hal ini sebagai bukti doa restu dari kedua belah pihak dan sebagai pengakuan dari masyarakat di ke diaman orang tua (Hamidin, 2012:96).

Desa Sako merupakan salah satu dari 19 desa atau kelurahan di wilayah kecamatan Rambutan, yang terletak $12 \mathrm{~km}$ kearah Timur dari kota kecamatan. Dengan jumlah penduduk berjumlah 575 kepala keluarga. Desa Sako kecamatan Rambutan kabupaten Banyuasin mempunyai luas wilayah seluas 2.801 hektar berbatasan langsung sebelah Utara berbatasan desa Menten, sebelah Selatan berbatasan desa Gelebak Dalam, sebelah Timur berbatasan desa Tanjung Marbu dan sebelah Barat berbatasan desa Pangkalan Gelebak.

Tingkat pendidikan terdiri dari PAUD, TK, SD, SMP, SMK yang terletak di desa Sako. Sedangkan SMA berada diluar desa Sako kecamatan Rambutan kabupaten Banyuasin. Setelah tamat dari SMA/SMK bagi yang mampu bisa melanjutkan ke universitas di Palembang dan bagi yang tidak mampu biasanya bisa mencari perkerjaan diluar desa Sako selain itu pekerjaan menjadi petani.

Mata pencarian masyarakat desa Sako adalah petani, berkebun di desa Sako mata pencarian sehari-hari adalah menyadap karet. Dengan demikian maka dapat disimpulkan mata pencarian masyarakat desa Sako adalah petani dan berkebun.

Adat adalah gagasan kebudayaan yang terdiri dari nilai-nilai kebudayaan norma, kebiasaan, kelembagaan, dan hukum adat yang lazim di suatu daerah. Apabila adat ini tidak dilaksanakan akan terjadi kerancuan yang menimbulkan sanksi tak tertulis oleh masyarakat terhadap prilaku (http://id.wikipedia.org/wiki/Adat).

Perkawinan adat Melayu memiliki banyak tahapan yang harus dilalui, mulai dari memikirkan proses akan menikah, persiapan perkawinan, upacara pada hari perkawinan, hingga setelah upacara perkawinan usai digelar. Sehingga, jika dilihat sepintas upacara perkawinan adat melayu terkesan rumit. Namun, dalam setiap tahap yang dilalui, terkandung makna yang sangat mendalam. Dan, hal itulah yang memberikan dorongan bahwa tahapan-tahapan perkawinan harus dilaksanakan (Hamidin, 2012:96-97).

Perkawinan adalah merupakan sunnah Nabi, yaitu mencontoh perbuatan yang dilakukan Nabi Muhammad S.A.W. Oleh karena itu bagi pengikut Nabi Muhammad S.A.W. yang baik maka mereka harus melaksanakan perkawinan. Selain mencontoh tindak laku Nabi Muhammad, juga perkawinan itu merupakan kehendak kemanusiaan. Kebutuhan rohani dan jasmani. Perkawinan disyariatkan supaya manusia mempunyai keturunan dan keluarga yang sah menuju kehidupan bahagia di dunia dan di akhirat, di bawah naungan cinta kasih dan ridla ilahi (Sosroatmodjo, 1978:33).

Palembang adalah provinsi yang cukup penting dalam menyumbang khasanah 
artefak seni dan budaya di Indonesia. Hal ini didukung pula dengan adanya catatan keberadaan kerajaan besar Sriwijaya dan Melayu yang pernah ada di wilayah ini beberapa abad lalu.

Indonesia pada umumnya dipengaruhi oleh hadirnya kebudayaan tertentu yang diawali dari masa prasejarah, klasik, awal, masa Hindu dan Budha hingga datangnya Islam. Fakta sejarah menunjukan, bahwa perkembangan seni dan budaya tradisional di Indonesia, telah mendapat pengaruh kebudayaan asing yang cikal-bakalnya sudah ada sejak zaman prasejarah.

Berdasarkan hasil studi perbandingan bahasa serumpun dengan bahasa Austronesia atau Melayu Polinesia, disimpulkan bahwa bangsa-bangsa pendukung Austronesia berasal dari daerah Champa, Chohin-China, dan Kamboja. Akar bahasa Austronesia kemungkinan besar berasal dari pantai China Selatan, dimulai dari bahasa Proto-Austronesia yang berasal dari Taiwan, kemudian menyebar ke Filipina, Kalimantan, dan Sulawesi, dan akhirnya bercabang dua, yang satu menyebar ke Barat yaitu ke Jawa, Sumatera, dan Semenanjung Melayu yang lain menyebar ke Timur melalui Halmahera ke wilayah Ocenia. Di Indonesia, secara garis besar dapat dikatakan, bahwa yang menjadi tulang punggung terbentuknya budaya sebelum zaman sejarah adalah budaya paleolitik, kemudian berkembang menjadi budaya sebelum neolitik, dan akhirnya kebudayaan logam yang sering disebut kebudayaan Dongson.

Dalam konteks ini, tradisi dapat diterjemahkan sebagai kebiasaan yang diwariskan dari generasi ke generasi secara turun-temurun. Kebiasaan yang diwariskan mencakup berbagai nilai budaya, meliputi adat-istiadat, sistem kemasyarakatan, sistem pengetahuan, bahasa, kesenian, dan teknologi dalam pembuatan rumah. menyatakan, bahwa tradisi bearti suatu kebiasaan yang dilakukan dengan cara yang sama oleh beberapa generasi tanpa atau sedikit sekali mengalami perubahan, dengan kata lain kebiasaan yang sudah menjadi adat dan membudaya (Dafri, 2011:1-5).

Dapat disimpulkan bahwa etnik Melayu ada tradisi sebagai yang diwariskan dari generasi ke generasi secara turun temurun. Kebiasaan yang diwariskan mencakup berbagai nilai budaya, meliputi adat-istiadat, sistem kemasyarakatan, sistem pengetahuan, bahasa, kesenian, dan teknologi dalam pembuatan rumah. menyatakan, bahwa tradisi bearti suatu kebiasaan yang dilakukan dengan cara yang sama oleh beberapa generasi tanpa atau sedikit sekali mengalami perubahan, dengan kata lain kebiasaan yang sudah menjadi adat dan membudaya.

\section{B. METODE PENELITIAN}

Metode penelitian merupakan cara yang digunakan untuk menghasilkan produk tertentu, dan menguji keefektifan produk tersebut (Sugiyono, 2012:297). Sesuatu penelitian mengandung arti suatu kegiatan untuk mencari, mencatat, merumuskan, dan menganalisis sampai menyusun laporannya (Narbuko, 2010:1). Dari uraian diatas maka dapat disimpulkan bahwa pengertian metode penelitian adalah suatu kegiatan yang digunakan dalam mengumpulkan data, mencari, mencatat, merumuskan, serta menganalisis data-data yang akan diteliti. Dalam penelitian ini penelitian menggunakan metode kualitatif. "Metode Kualitatif "adalah metode yang membicarakan berupa pengamatan, wawancara atau penelaahan dokumen" (Meleong, 2010:9).

\section{Sumber Data \\ Pengamatan secara langsung}

Penelitian datang secara langsung ke lokasi penelitian dan mencatat secara sistematis terhadap gejala atau fenomena yang diteliti. Dengan pengamatan secara langsung peneliti dapat melihat tradisi "Adat Perkawinan Etnis Melayu Di Desa Sako 
Kecamatan Rambutan Kabupaten

Banyuasin".

Wawancara

Dengan teknik wawancara mendalam peneliti bertatap muka langsung dengan salah salah satu lembaga adat yaitu bapak Suadi Kanang untuk mengetahui bagaimana sejarah awal mengenai tradisi adat perkawinan etnis Melayu di desa Sako kecamatan Rambutan kabupaten Banyuasin.

\section{Dokumentasi}

Dokumentasi merupakan catatan peristiwa penting yang sudah berlalu. Dokumentasi bisa berbentuk tulisan, gambar, atau buku nikah, foto dan lainlainnya. Studi dokumen merupakan pelengkap dari pengguna metode wawancara dalam penelitian kualitatif.

\section{Teknik Analisis Data}

Teknik analisis data yang digunakan adalah teknik analisis data interaktif. meliputi: reduksi Data, Penyajian Data, Penarikan Kesimpulan dan Verifikasi

\section{HASIL DAN PEMBAHASAN}

\section{Adat Perkawinan Rasan Baek (Melalui Perkawinan)}

Adat perkawinan Upacara Rasan Baek (upacara melalui pertunangan) umumnya melalui tahapan pendekatan (Jajakan), pinangan (Maro Kato), pelamaran (melamar/pernikahan), menyerahkan tes kehamilan, pembayaran administrasi pernikahan dan menetapkan tanggal perayaan hingga meminta izin perayaan pada pihak yang mengizinkan.

Adapun proses adat perkawinan Rasan Baek (melalui perkawinan) Etnis Melayu di desa Sako adalah sebagai berikut:

\section{Jajakan}

Kegiatan Jajakan merupakan kegiatan paling awal jika seorang lelaki ingin menikahi seorang gadis. Jajakan adalah pendekatan atau penjajakan pihak laki-laki kepada keluarga pihak perempuan dengan mengutus wakil menemui keluarga pihak perempuan di rumahnya. Kegiatan ini merupakan awal sebelum masuk pada kegiatan Maro Kato. Wakil calon laki-laki mendatangi keluarga calon wanita dengan menyampaikan hajat kepada orang tua perempuan bahwa si laki-laki yang bernama $A$ ingin mempersunting (meminang) anaknya yang bernama B yang mereka sebut sirih hanyut atau pinang hanyut.

Menurut adat desa Sako, wakil pihak laki-laki yang melakukan Jajakan ke rumah keluarga perempuan membawa buah tangan (oleh-oleh) berupa gula, kopi, tembakau, getah sirih, rokok pucuk, bawang merah, bawang putih, garam dan minyak sayur sebagai bentuk hormat ingin melakukan pendekatan atas niat si $A$ ingin menikahi B. Dengan cara ini diharapkan pendekatan yang dilakukan dapat diterima oleh pihak keluarga perempuan sehingga dapt dilakukan upacara selanjutnya yaitu Maro Kato yang harinya diatur kapan bisa dilaksanakan (Rokian, 2014:87).

\section{Maro Kato}

Kegiatan Maro Kato adalah proses pinangan yang harus didahului pihak calon mempelai laki-laki setelah melewati kegiatan penjajakan (jajakan) tadi. Maro Kato dilakukan oleh keluarga calon mempelai laki-laki ke rumah calon mempelai wanita dengan cara sebagai berikut:

a) Rombongan calon mempelai laki-laki pergi ke rumah calon mempelai perempuan yang diketuai oleh salah seorang juru bicara (jubir). Waktu kedatangan sudah diatur bersama sehingga perkiraan rombongan pihak laki-laki akan sampai di rumah pihak perempuan (tempat acara Maro Kato) sesuai kesepakatan/tepat waktu. Lembaga Adat desa Sako menetapkan untuk Maro Kato rombongan pihak lakilaki harus membawa buah tangan berupa: wajik bulat tujuh buah, pisang ambon atau kerupuk, dasar baju untuk wanita lengkap, pisau berangko, sisir, cermin dan bedak serta sumpit berisi 
daun sirih, getah, kapur dan buah pinang (jambe).

Sesampainya di depan rumah calon mempelai wanita rombongan ini harus berdiri sebentar menunggu tanggapan dari tuan rumah (pihak keluarga perempuan). Kemudian keluarga pihak perempuan diwakili salah seorang mendatangi rombongan sambil mengucapkan serbah atau kata-kata penyambutan yang berbunyi:

"Diaturi, laju calon besan silakan naik, Inilah dikator akar boloh,

Dinding melepuh kulit.

Garang condong ke mato ari mati, Kur semangat nyo....

Setelah adanya upacara ini, maka rombongan pihak laki-laki yang membawa buah tangan (oleh-oleh) tadi langsung naik ke rumah keluarga pihak perempuan.

Setelah di dalam rumah, buah tangan atau disebut juga gawaan diatur tempatnya pada tempat yang telah disediakan pihak keluarga perempuan.

Kemudian dilakukan acara pembukaan oleh pembawa acara (MC). Pembawa acara melalui acara dengan mengajak hadirin melafazkan Basmalah yang dilanjutkan dengan kata sambutan dari pihak perempuan.

Selanjutnya juru bicara pihak lakilaki menyampaikan maksud dan tujuan kedatangan kepada ketua lembaga adat sekaligus meminta diperiksa kelengkapan syarat-syarat adat oleh-oleh (buah tangan) yang dibawa rombongan. Kemudian juru bicara pihak laki-laki menyampaikan tujuan dengan pihak perempuan. Pada tahapan ini antara pihak laki-laki dan pihak perempuan biasanya saling pantun bersambut kepada masing-masing pihak.

Bila hajat yang disampaikan pihak laki-laki disambut baik oleh pihak perempuan atau dijawab dengan kata sepakat/setuju untuk menikahkan calon mempelai laki-laki dengan calon mempelai wanita maka acara dilanjutkan dengan serah-serahan (menyerahkan) buah tangan (gawaan) yang dibawa tadi kepada orang tua calon mempelai wanita yang disaksikan oleh sanak famili yang hadir.

Ucapan yang disampaikan juru bicara pihak pria kepada orang tua calon mempelai wanita umumnya berbunyi: "Kami mewakili keluarga bapak $C$ (orang tua dari A si laki-laki) menyampaikan bahwa kami ini membawa gawaan/oleholeh. Gawaan ini kalu dinilai dengan harganya tidaklah seberapa. Ini hanyalah merupakan ungkapan cinta hati kami sekeluarga dan tolong diterimakan barang gawaan ini." Lalu barang gawaan tersebut diserahkan secara simbolis oleh pihak keluarga laki-laki kepada calon mempelai wanita. Kemudian pihak keluarga laki-laki kepada pihak calon mempelai wanita. Kemudian pihak keluarga wanita menyerahkan kembali barang-barang (oleh-oleh) tersebut secara simbolis pula kepada ketua lembaga adat desa. Ketua adat selanjutnya melihat atau memeriksa syarat-syarat adat yang dibawa (gawaan) tersebut apakah sudah lengkap.

Ketua Lembaga Adat setelah memeriksa gawaan tadi lengkap sesuai dengan syarat-syarat adat berpidato menyampaikan bahwa sudah lengkap dan dipersilahkan memasuki proses Maro Kato atau menentukan waktu acara untuk melamar.

Kegiatan ini kemudian ditutup dengan membuka kesempatan saling maaf dan terima kasih atas pertemuan Upacara Maro Kato (pinangan) lalu ditutup dengan:

1. Do'a bersama

2. Ramah tamah makan (santapan)

3. Rombongan Pamit Pulang.

"Datang tampak muka dan pulang tampak punggung". Pihak calon mempelai laki-laki maupun perempuan 
kembali mengucapakan rasa terima kasih dan mohon maaf.

Jarak antara Upacara Maro Kato sampai menuju upacara melamar diberi waktu tiga bulan. Jika terjadi hal yang tidak diinginkan misalnya calon mempelai laki-laki sampai masa tiga bulan tidak ada kabar berita atau calon mempelai wanita memilih lelaki lain, maka ada sejumlah sanksi maro yang berlaku terhadap mereka, yaitu:

Apabila sampai tiga bulan pihak lakilaki tidak ada kabar berita, tidak ada tuntutan kepada pihak perempuan untuk mengambil langkah lain.

Tidak ada tuntutan/ganti rugi kepada pihak perempuan, apabila pihak laki-laki meninggalkan pihak perempuaan terlebih dahulu, namun pihak laki-laki meninggalkan pihak perempuan tadi dikenakan sanksi adat dengan nilai $50 \%$ dari nilai bawaan maro, karena sudah tidak menghargai adat dan kesopanan.

Pihak perempuan dituntut mengganti 2 kali lipat terhadap pihak laki-laki apabila pihak perempuan meninggalkan pihak lakilaki dan membayar denda kepada pihak Lembaga Adat $50 \%$ dari nilai bawaan maro, karena telah tidak menghargai adat dan kesopanan.

Apabila Maro Kato telah dilaksanakan, tetapi mereka malanggar adat istiadat dengan melakukan pelarian (larian) maka kedua belah pihak diberikan sanksi-sanksi membayar denda $50 \%$ dari nilai bawaan maro kepada Lembaga Adat (Rokian, 2014:87-88).

\section{Melamar}

Proses acara melamar sama saja dengan melaksanakan acara pinang/Maro Kato hanya saja sedikit ditambah dan perubahan bentuk barang bawa-bawaan atau buah tangan dengan syarat utama pinangan lengkap (wajib) yaitu: sirih, tembakau, rokok pucuk atau rokok biasa dibungkus rapi, dasar baju, kain bersalin, handuk, selendang, pakaian dalam dan sandal serta alat tidur lengkap untuk calon mempelai perempuan, sisir, cermin dan alat kosmetik, wajik, dodol, sangon, pisang ambon dan kerupuk, dan kelapa hias dua buah. Selain itu masih ada barang bawaan lainnya bersifat tambahan penting: pisau berangko, uang atau barang penghargaan untuk calon mempelai perempuan (PETUKON), uang yang diberikan kepada orang tua calon mempelai perempuan (JUJUR) uang kawin sesuai dengan kesepakatan kedua calon mempelai (MAHAR). Sedangkan proses pelamaran sama seperti acara pinangan/Maro Kato (Rokian, 2014:88-89).

\section{Ngaesi Rumah}

Ngaesi Rumah adalah kegiatan menghiasi rumah pengantin dan menghiasi tempat kamar tidur pengantin. Kegiatan ini dilakukan sebelum seminggu perkawinan (Wawancara, Suadi Kanang, 29 Juni 2016).

\section{Gotong-royong}

Gotong-royong yang dilakukan bapakbapak dan anak muda untuk membuat keperluan hari pernikahan seperti membuat bale (panggung) dari kayu yang diatapi nipah yang dilakukan anak-anak muda setelah selesai membuat panggung bapakbapak dan anak muda bergotong royong lagi menyembelih hewan kambing dan ayam, dan megupas kelapa. Setelah pekerjaan tersebut selesai bapak-bapak dan anak-anak muda tadi istirahat. Sedangkan ibu-ibunya memasak dan menyiapkan kue kering dan kue basah ketupat untuk makan bersama-sama dirumah hajatan. Setelah makan-makan tadi ibu-ibu melanjutkan memasak gulai ayam dan daging. Masakan itu untuk persiapan para tamu, besan dan keluarga.

Gotong royong yang dilakukan bapakbapak dan ibu-ibu membuat keperluan hari pernikahan seperti membuat panggung dari kayu yang di atapi nipa bapak-bapak dan anak muda bergotong royong lagi menyembelih hewan kerbau, kambing, 
ayam, dan megumpas kelapan

(Wawancara, Suadi Kanang, 29 Juni 2016).

\section{Berpacar Kuku}

Berpacar kuku adalah kegiatan untuk memerahkan kuku yang terbuat dari pacar kayu diberik nasi dan arang. Kegiatan ini masing-masing dilakukan di rumah calon pengantin. Dalam Kegiatan ini dilakukan seminggu sebelum perkawinan.

Dari hasil wawancara diatas dapat disimpulkan bahwa berpacar kuku adalah untuk memerahkan kuku dirumah masingmasing calon pengantin. Dalam Kegiatan ini dilakukan seminggu sebelum perkawinan (Wawancara, Suadi Kanang, 29 Juni 2016).

\section{Berbedak Tepung Beras Kunyit}

Berbedak tepung beras kunyit ialah untuk mempercantik kulit calon pengantin wanita kegiatan ini dilakukan sebelum seminggu perkawinan. Bebedak tepung beras kunyit ialah untuk mempercantik kulit calon pengantin wanita kegiatan ini dilakukan sebelum seminggu perkawinan (Wawancara, Suadi Kanang, 29 Juni 2016).

\section{Ziarah Makam}

Ziarah kubur dilakukan sebelum seminggu perkawinan dilangsungkan. Dalam acara ini, calon pengantin pria dan pengantin wanita pergi berziarah ke makam Bapak atau ibu nya yang sudah tidak ada lagi. Tujuannya supaya pada hari pernikahannya berjalan dengan lancar. ziarah kubur dilakukan sebelum seminggu perkawinan dilangsungkan. Dalam acara ini, calon pengantin pria dan pengantin wanita pergi berziarah ke makam-makam. Tujuannya supaya pada hari pernikahannya berjalan dengan lancar (Wawancara, Suadi Kanang, 29 Juni 2016).

\section{Upacara Pernikahan}

Dalam kaitan pernikahan ini 10 hari sebelum akad nikah dilaksanakan calon mempelai perempuan harus melampirkan surat tes kehamilan dari bidan setempat, untuk melengkapi syarat pengambilan surat nikah. Hasil tes kehamilan dari bidan diberikan kepada Lembaga Pembina Adat untuk diketahui hasil tes urine tersebut positif atau negatif dan di copy dalam dua rangkap. Satu rangkap diberikan kepada lembaga adat dan satu rangkap lagi untuk calon mempelai pria-wanita. Apabila hasil tes urine calon mempelai perempuan negatif maka proses pengambilan NA tidak ada hambatan, sekaligus membayar uang administrasi nikah sekaligus pengaturan tanggal hari pelaksanaan perayaan (munggah) di Kepala Desa. Saat itu juga bisa dibayar uang izin perayaannya.

Jika semuanya sudah diurus maka tinggal menjalankan pelaksanaan upacara pernikahan dan upacara munggah (perayaan pernikahan). Namun, apabila hasil tes urine calon mempelai perempuan tersebut positif hamil maka acara pelamaran dibatalkan dan calon mempelai harus dikawinkan dengan cara proses rasan jahat kemudian mereka harus membayar sanksi/denda adat dengan niali $50 \%$ dari nilai bawaan maro (Rokian, 2014:89).

\section{Adat Perkawinan Rasan Jahat (Tanpa Melalui Pertunangan)}

Rasan Jahat adalah upacara persiapan pernikahan atau perjodohan di Desa Sako contohnya yang bukan dilakukan melalui rasan baik atau tanpa melalui pertunangan, karena itu rasan jahat tanpa melalui proses Maro Kato, namun langsung melakukan akad nikah yang dilaksanakan di kantor pemerintahan dimana calon kedua mempelai meminta perlindungan. Itu artinya kedua mempelai tidak melaksanakan rasan baik. Menurut adat Sako pasangan pria dan wanita yang menggunakan rasan jahat konsekuensinya kedua calon pengantin harus membayar uang penginapan dimana tempat mereka meminta perlindungan. Uang penginapan ini disesuaikan dengan keadaan saat itu, namun kalau dahulu biaya penginapan itu sebesar Rp. 30. 000,- per hari dikalikan dengan berapa hari mereka 
menginap di rumah pemerintahan yang mereka tumpangi. Maksud rumah pemerintahan ini bisa pemangku adat, kepala desa, kepala dusun atau ketua RT setempat sebagai tempat mereka meminta perlindungan.

Upacara rasan jahat diikuti dengan beberapa kegiatan yaitu:

\section{Rasan Tende Gadih}

Kegiatan ini calon pria menyerahkan barang atau pakaian milik calon mempelai perempuan/gadis ke rumah pemerintahan serta dilampir surat pernyataan dari kedua belah pihak yang ditulis diatas kertas. Surat pernyataan yang merupakan bentuk laporan untuk menikah tanpa melalui rasan baik atau melalui rasan jahat ini diterima oleh pemerintah yang bersangkutan, sehingga proses Maro Kato otomatis ditiadakan, namun proses lamaran tetap dilaksanakan.

\section{Rasan Anjrek}

Kegiatan ini calon mempelai pria langsung menghadap orang tua perempuan/gadis menyatakan ingin menikahi anaknya dan siap menyatu dalam keluarga besar setelah menjadi suami anak mereka. Orang tua gadis biasanya setuju dan menerima permintaan calon mempelai pria. Kemudian orang tua perempuan melapor ke pemerintah setempat atau kepada ketua lembaga adat untuk proses akad nikah walaupun tanpa restu orang tua laki-laki, kecuali ada kesepakatan diantara kedua belah pihak. Rasan Anjrek ini mengakibatkan secara resmi hilangnya Maro tapi langsung melamar dan biaya pelaksanaan pernikahan ditanggung oleh pihak orang tua perempuan kecuali ada kesepakatan untuk menanggung bersama.

\section{Rasan Pernyataan Surat}

Kegiatan ini merupakan proses kesepakatan antara muda mudi diungkapkan melalui surat pernyataan di atas kertas bermaterai dan ditandatangani oleh kedua belah pihak serta ditandatangani dua orang saksi. Surat itu kemudian diantarkan oleh pihak calon mempelai lakilaki kepada pemerintah setempat untuk ditindaklanjuti. Maka proses ini sama dengan proses Tende Gadih (Rokian, 2014:89).

\section{Sanksi-sanksi Rasan Jahat}

Apabila terjadi pergaulan muda-mudi bujang gadis bergaul bebas mengakibatkan kejanggalan dalam pandangan masyarakat banyak (sampai hamil) maka yang bersangkutan cukup dengan dinikahkan saja, tidak diizinkan mengadakan perayaan dan pasangan ini dikenakan sanksi adat dengan nilai uang Rp. 500.000,- (lima ratus ribu rupiah).

Menyembelih kambing dengan syarat ukuran syarat kambing untuk korban minimal umur kambing dua tahun.

Sebelum kambing disembelih, kambing tersebut harus ditarik laki-laki dan perempuan menuju tempat penyembelihan yang ditentukan yang disaksikan oleh masyarakat.

Apabila si perempuan hamil kurang dalam waktu enam bulan terhitung dari saat akad nikah maka apabila anak itu lahir perempuan, anak perempuan tersebut wali nikah nantinya adalah wali hakim dan orang tuanya diakad nikahkan ulang, menurut Hukum Agama Islam (Rokian, 2014:90).

\section{Acara Mengarak Pengantin}

Menurut tradisi di Banyuasin seminggu sebelum arak-arakan baik calon mempelai pria maupun calon mempelai wanita biasanya melakukan aktivitas betangas di rumah masing-masing, yaitu kegiatan mirip mandi uap yang ditutupi tikar/selimut tebal duduk di kursi kayu di bawahnya diberi ramuan tanpa bara api untuk menghilangkan keringat di dalam tubuh guna membuat badan selalu segar bugar.

Kemudian sesuai kesepakatan hari dan waktunya diadakanlah acara arak-arakan calon pengantin pria menuju rumah calon pengantin wanita. Sebelum arak-arakan biasanya sudah ada kesepakatan barang 
apa saja yang akan dibawa kepada keluarga calon pengantin wanita sebelum berlangsungnya akad nikah.

Sebelum arak-arakan dimulai, keluarga calon pengantin pria memeriksa semua barang yang disepakati untuk dibawa antara lain wajik, pisang, kue bolu, kue engkak, kue lapis, kue maksuba, kecap, beras, cabe kiloan dan lainnya serta uang dan emas mahar pernikahan.

Calon mempelai pria biasanya dihiasi pakaian jubah dan memakai igal dikepalanya, sedangkan yang ikut mengarak ketua adat, alim ulama, kiayi, tokoh-tokoh keluarga dan jru bicara yaitu penggawa, berseragam jas teluk belango dan ibuibunya berpakaian muslimah/kebaya. Kini arakan pengantin tidak seketat dulu harus melibatkan tokoh adat. Kadang-kadang hanya diiringi keluarga dan tokoh biasa, malahan juru bicaranya sering diwakili orang berpangkat, berpengaruh atau yang berpengalaman bisa berbicara saja.

Peserta arak-arakan dibagian depan calon pengantin pria dan kedua orang tuanya terdiri dari perangkat adat, alim ulama dan para tetua lainnya dan di bagian belakang adalah kaum generasi muda. Kalau dahulu arak-arakan pengantin diiringi dengan seni tari pencak silat, namun sekarang diringi oleh grup rebana atau musik tanjidor karena para pendekar seni pencak silat sekarang sudah sangat langka. Sementara pada keluarga calon pengantin wanita sudah menunggu di rumahnya. Mereka terdiri dari kedua orang tuanya, kakek-neneknya, uwak-uwaknya, pamanbibinya para keluarga lainnya serta sesepuh adat setempat.

Jika arak-arakan sudah tiba di depan rumah mempelai wanita, keluarga mempelai wanita mempersilahkan calon pengantin pria dan peserta arakan untuk naik ke rumah calon mempelai wanita guna menyampaikan hajatnya. Juru bicara mempelai pria menyampaikan keinginan keluarga hendak menikahkan calon pengantin pria dengan calon mempelai wanita. Dialog biasanya disertai pantun bersahut yang intinya; "Kami sengaja datang membawa bujang tampan ini untuk dinikahkan". Saat itu juga pihak calon mempelai wanita biasanya menjawab: "Kami pihak mempelai wanita juga sudah siap menerima untuk dinikahkan". Biasanya setelah ada kata sepakat seperti itu, kedua belah pihak setuju untuk langsung melangsungkan akad nikah (Wawancara, Suadi Kanang, 29 Juni 2016).

Selesai arak-arakan, akad nikah dan perayaan pernikahan selesai menurut adat Banyuasin pengantin pria belum boleh bercampur dengan pengantin wanita. Hari itu dia harus pulang dulu bersam keluarganya sampai tiga hari kemudian. Baru pada malam ketiga harinya diantarkan kembali oleh keluarganya menuju rumah pengantin wanita kalau dulu dengan penerangan strongking membawa koper berisi pakaian pengantin pria seperti telukbelango, kain, handuk dan segala keperluan lainnya. Sesampainya di rumah pengantin wanita, menurut adat, pengantin pria tidak bisa serta merta bisa masuk kamar pengantin, harus menunggu izin mempelai wanita untuk boleh masuk tidak. Jika mempelai wanita belum siap maka mempelai pria setia menunggu di luar kamar, namun lazimnya pengantin wanita kasihan langsung mengizinkan kekasih hatinya untuk masuk kamar pengantin (Wawancara, Suadi Kanang, 29 Juni 2016).

\section{SIMPULAN}

Pada bagian akhir dari Penelitian ini penulis memberikan simpulannya, yaitu:

1. Perkawinan adat Etnis Melayu merupakan fase yang memiliki nilai moral (sakral) dan amat penting. Oleh sebab itu, keterlibatan dalam upacara perkawinan tersebut tidak hanya pasangan pengantin saja, tetapi juga keluarga, kerabat dekat kedua belah pihak. Hal ini sebagai bukti doa restu dari kedua belah pihak sekaligus sebagai pengakuan. 
2. Adat perkawinan Etnis Melayu di desa Sako terbagi menjadi dua cara yaitu yang pertama Adat Perkawinan Rasan Baik (Melalui Pertunangan) melalui proses Jajakan, Maro Kato, Melamar, dan Upacara Pernikahan. Kedua Rasan Jahat (Tanpa Melalui Pertunangan) yang diikuti beberapa kegiatan yaitu Rasan Tende Gadih, Rasan Anjrek, Rasan Pernyataan Surat dan selanjutnya dilakukan Acara Mengarak Pengantin.

\section{DAFTAR PUSTAKA}

Abdurahman, Dudung. 2007. Metode Penelitian Sejarah. Yogyakarta: PT. Renika Cipta.

Fathoni, Abdurrahmat. 2005. Metodologi Penelitian \& Teknik Penyusunan Pen elitian. Garut: Rineka Cipta.

Dafri, Yulriawan. 2007. Melacak Jejak Artefak Seni Etnik Melayu. Palembang: Gama Media.

Hamidin, Aep S. 2012. Buku Pintar Adat Perkawinan Nusantara. Jogjakarta: PT Diva Press.

Hadikusuma, Hilman. 1997. Hukum Perkawinan Adat. Bandung: PT. Alumni.

Hadikusuma, Hilman. 2007. Hukum Perkawinan Indonesia. Bandung: Mandar Maju.

Koentjaraningrat, 2009. Pengantar IImu Antropologi. Jakarta: PT. Rineka Cipta.
Meleong, Lexy J. 2010. Metodelogi

Penelitian Kualitatif. Bandung: PT. Remaja Rosdakarya.

Narbuko, Cholid dan Abu Achmadi. 2012. Metode Penelitian Teoritis. Jakarta: Bumi Aksara.

Rasjid, Sulaiman. 1986. Fioh Islam. Jakarta: PT. Sinar Baru Algensindo.

Rokian, Ajmal. 2014. Sejarah, Khasanah Budaya dan Profil Potensi Kabupaten Banyuasin. Banyuasin: Dinas Pariwisata, Seni, Budaya, Pemuda dan Olahraga Kabupaten Banyuasin, Sumatera Selatan.

Sosroatmodjo, Asro, dan Aulawi, Wasit. 1975. Hukum Perkawinan Di Indonesia. Jakarta: Bulan Bintang.

Sudarsono, 2010. Hukum Perkawinan Nasional. Jakarta: PT. Rineka Cipta.

Sugiyono, 2009. Metode Penelitian, Kuantitatif, Kualitatif, dan $R$ dan $D$. Bandung: Alfabeta.

Sugiyono, 2012. Metode Penelitian Pendidikan. Bandung: Alfabeta.

Suryabrata, Sumadi. 2003. Metodologi Penelitian. Jakarta: PT. Raja Grafindo Persada.

Kanang, Suadi, 2015. Profil Desa Sako Kecamatan Rambutan Kabupaten Banyuasin. Banyuasin. Pemerintah Desa Sako Kecamatan Rambutan Kabupaten Banyuasin.

\section{Sumber Internet:}

(http://id.wikipedia.org/wiki/Adat). 